\title{
Remediasi Miskonsepsi Pada Materi Gelombang Bunyi Dengan Pendekatan Konstruktivisme Metode 5E Di SMA N 1 Turi
}

\author{
Ari Shinta Widiastuti ${ }^{1}$, Joko Purwanto ${ }^{2}$ \\ 1,2 Program Studi S1 Pendidikan Fisika, Universitas Islam Negeri Sunan Kalijaga Yogyakarta, \\ Jl. Marsda Adisucipto No 14, Sleman, D.I. Yogyakarta \\ Email : arishintawidiastuti11@gmail.com
}

\begin{abstract}
Knowledge construction from the beginning before students get formal learning (preconceptions or students' initial concepts) often does not match the knowledge received by experts, and becomes a misconception. Misconceptions on students need to be diagnosed and given a solution to improve learning, so that misunderstanding of the material can be corrected. This study aims to determine the effectiveness of the constructivism approach with the $5 E$ method to remedy misconceptions on sound wave material. This research is a qualitative descriptive study with a sample of students of class XI MIPA 2 in 1 Turi Senior High School. This study uses a two tier test instrument. In addition to using a two tier test, interviews were conducted on several students to confirm the answers to the two tier test. Based on the results data, it was found that learning using the constructivism approach with the 5E method was effective in minimizing the average of students' misconceptions of $26 \%$.
\end{abstract}

Keywords: Misconceptions, Sound Waves, Remediation, Constructivist, 5E Methods.

\section{PENDAHULUAN}

Salah satu tujuan penting pembelajaran fisika adalah mengantarkan peserta didik memahami secara mendalam konsep-konsep dasar dalam fisika sehingga mampu menerapkannya untuk memecahkan masalah (Sutopo, 2016). Dalam pembelajaran peserta didik dapat menggunakan konsep-konsep yang telah ada untuk menghadapi gejala baru dengan perubahan kecil (penyesuaian) atau bahkan peserta didik harus mengganti dan mengubah konsep-konsep pokok yang telah dimiliki karena tidak cocok dengan persoalan yang baru (Suparno, 2013). Namun, pada umumnya peserta didik memiliki sedikit kemampuan untuk menghubungkan konsep yang dipelajari dari buku maupun lingkungannya (Taufiq, 2012).

Peserta didik dalam mengikuti proses pembelajaran fisika secara formal akan membawa pengalaman-pengalaman sebagai pengetahuan awal untuk menghubungkan konsep yang dipelajari dengan pengalaman dari peristiwa dalam lingkungan sehari-hari. Hal ini karena peserta didik tidak memasuki pembelajaran dengan kepala kosong yang dapat diisi dengan pengetahuan fisika. Peserta didik telah berpengalaman dengan peristiwa fisika, pengalaman tersebut telah membentuk (mengkonstruksi) intuisi dan "teori peserta didik" (Berg,1991). Tongchai (2009) menyatakan bahwa banyak penelitian menunjukkan bahwa peserta didik memasuki ruangan kelas dengan konsepsi yang bertentangan dengan ide-ide ilmiah yang diterima saat ini atau miskonsepsi, misalnya penelitian Hewson (1983), Tytler (2000), dan Heikkinen (2000).

Besarnya perhatian para peneliti pada pemahaman konseptual diikuti dengan banyaknya penelitian untuk mengukur dan meningkatkan pemahaman konseptual. Namun, sebagian besar dari peneliti lebih memilih bidang mekanika Newton dibandingkan dengan topik gelombang. Hal ini disebabkan para peneliti memiliki pemikiran bahwa mekanika Newtonian merupakan cabang fisika yang sangat esensial (Sutopo, 2016). Padahal, beberapa penelitian 
menunjukkan bahwa peserta didik mengalami miskonsepsi pada materi gelombang bunyi (Amina, 2007; Sutopo, 2016; Barniol, 2016). Hal ini sejalan dengan identifikasi miskonsepsi yang dilakukan di SMA N 1 Turi bahwa sebagian besar peserta didik mengalami miskonsepsi pada materi gelombang bunyi.

Adanya miskonsepsi pada peserta didik dapat menghambat proses pembelajaran saat konsep lama yang keliru berbenturan dengan konsep baru yang benar (Viridi, 2008). Oleh karena itu, penting untuk melakukan remediasi. Remediasi merupakan kegiatan untuk mengurangi atau meminimalkan miskonsepsi (Sutrisno dkk, 2007). Terdapat banyak cara untuk melakukan remediasi kepada peserta didik. Namun, tidak semua cara sesuai bagi peserta didik yang mengalami miskonsepsi. Kunci untuk memperbaiki miskonsepsi adalah interaksi dengan peserta didik (Berg, 1991). Salah satu cara efektif untuk melibatkan peserta didik dalam proses pembelajaran dengan menggunakan pendekatan konstruktivisme. Pendekatan konstruktivisme dapat mendorong peserta didik mengemukakan pengetahuan, menemukan konsep, membangun konsep, dan memungkinkan peserta didik untuk mengaplikasi pemahaman konsep peserta didik melalui interaksi sosial. Berdasarkan penelitian Altun dan Toy (2015) bahwa penciptaan suasana kompetitif memastikan bahwa peserta didik memainkan peran lebih aktif dalam proses pembelajaran dan lebih menyenangkan serta seperti yang diinginkan peserta didik.

Mengingat tujuan remediasi adalah memperbaiki kesalahan pada konsep peserta didik dan pentingnya interaksi sosial atau partisipasi peserta didik dalam pembelajaran maka diperlukan juga metode pembelajaran yang sesuai dengan pendekatan tersebut, yaitu metode $5 \mathrm{E}$ (engange, explore, explain, extend, evaluated). 5E juga dapat mengakomodasi kegiatan pemberian pertanyaan, ekperimen (hukum alam selalu benar), situasi hipotesis tanpa didasari hukum fisika, dan ekperiemen atau demonstrasi untuk menguji hipotesis (Taufiq, 2012). Menurut Challenger dalam Ergin (2012) salah satu cara paling efektif melibatkan peserta didik dalam pembelajaran dengan menggunakan 5E. Urutan pelajaran yang dirancang untuk menantang konsep saat ini dapat membantu peserta didik untuk merekonstruksi konsep sendiri. Metode 5E juga dapat mengakomodasi kegiatan pemberian pertanyaan, ekperimen (hukum alam selalu benar), situasi hipotesis tanpa didasari hukum fisika, dan ekperiemen atau demonstrasi untuk menguji hipotesis (Taufiq, 2012). Karena menurut Halloun dan Hestenes dalam Berg (1991) dengan ceramah yang bagus, miskonsepsi tidak dapat dihilangkan dan dihindari.

Berdasarkan kajian literatur penelitian sains mengungkapkan bahwa pendekatan konstruktivisme dengan metode 5E merupakan salah satu cara remediasi yang tepat. Hal ini dapat terlihat dari penelitian yang menunjukan bahwa metode 5E meningkatkan peran aktif peserta didik dan menghubungkan pengetahuan yang telah mereka miliki dengan dunia nyata (Ergin, 2012), serta mengungkapkan penurunan jumlah peserta didik yang mengalami miskonsepsi (Taufiq, 2012).

Berdasarkan uraian di atas, tentunya sangat penting melakukan remediasi miskonsepsi di SMA N 1 Turi karena miskonsepsi dapat menghambat proses pembelajaran dan konstruksi pengetahuan peserta didik. Oleh karena itu, penelitian ini bertujuan untuk merediasi miskonsepsi peserta didik pada materi gelombang bunyi dengan pendekatan konstrutivisme metode 5E di SMA N 1 Turi.

\section{METODE PENELITIAN}

Penelitian ini merupakan penelitian deskriptif kualitatif dengan sampel 30 peserta didik kelas XI MIPA 2 di SMA N 1 Turi yang telah menerima materi gelombang bunyi. Instrumen yang digunakan adalah lembar tes diagnostik. Tes diagnostik berjumlah 9 butir soal (Tabel 1) 
dengan penambahan alasan terbuka yang diadaptasi dari the mechanical waves conceptual survey dikembangkan oleh Pablo Barniol untuk kemudian dilakukan alih bahasa.

Tabel 1 Sebaran Indikator Soal pada Setiap Konsep

\begin{tabular}{|c|c|c|c|}
\hline No & Konsep & Indikator Soal & $\begin{array}{l}\text { Nomor } \\
\text { Soal }\end{array}$ \\
\hline \multirow[t]{6}{*}{1} & \multirow{6}{*}{$\begin{array}{l}\text { Cepat rambat } \\
\text { gelombang bunyi di } \\
\text { udara }\end{array}$} & Menganalisis amplitudo dan frekuensi & 1 \\
\hline & & $\begin{array}{l}\text { Menyimpulkan kecepatan rambat gelombang } \\
\text { tidak bergantung frekuensi }\end{array}$ & 2 \\
\hline & & $\begin{array}{l}\text { Menyimpulkan kecepatan rambat gelombang } \\
\text { tidak bergantung frekuensi dan amplitudo }\end{array}$ & 3 \\
\hline & & $\begin{array}{l}\text { Mengemukakan osilasi partikel udara terganggu } \\
\text { oleh gelombang bunyi }\end{array}$ & 4 \\
\hline & & $\begin{array}{l}\text { Mengkorelasikan frekuensi gelombang bunyi } \\
\text { dengan osilasi }\end{array}$ & 5 \\
\hline & & $\begin{array}{l}\text { Mengemukakan amplitudo gelombang dengan } \\
\text { osilasi }\end{array}$ & 6 \\
\hline \multirow[t]{3}{*}{2} & \multirow[t]{3}{*}{ Pipa organa } & $\begin{array}{l}\text { Menggambarkan bentuk panjang gelombang pada } \\
\text { pipa organa tertutup }\end{array}$ & 7 \\
\hline & & $\begin{array}{l}\text { Menggambarkan panjang gelombang pipa organa } \\
\text { terbuka }\end{array}$ & 8 \\
\hline & & $\begin{array}{l}\text { Mengaitkan peruabahan volume udara dengan } \\
\text { nada yang dihasilakan }\end{array}$ & 9 \\
\hline
\end{tabular}

Data hasil tes diagnostik dianalisis dengan kategori memahami, miskonsepsi, dan tidak memahami dapat dilihat dari setiap pilihan jawaban dan alasan peserta didik kemungkinan jawaban dari peserta didik dapat dilihat pada Tabel 2 berikut:

Tabel 2 Kemungkinan Pola Jawaban Peserta Didik dan Kategorinya

\begin{tabular}{ccc}
\hline No & Pola Jawaban Peserta Didik & Kategori Tingkat Pemahaman \\
\hline 1. & Jawaban inti tes benar - alasan benar & Memahami \\
2. & Jawaban inti tes benar - alasan salah & Miskonsepsi \\
3. & Jawaban inti tes salah - alasan benar & Miskonsepsi \\
4. & Jawaban inti tes salah - alasan salah & Miskonsepsi \\
& Jawhoungan) & \\
5. & Tidak Paham Konsep \\
\hline
\end{tabular}

Sumber (Siswaningsih, 2017)

Untuk mengetahui persentase jawaban tes diagnostik peserta didik pada setiap kategori yaitu memahami, miskonsepsi, dan tidak memahami. Digunakan rumus sebagai berikut:

$$
\frac{\sum M}{\sum N} x 100 \%
$$

dengan $\sum M=$ jumlah peserta didik pada setiap kategori

$\sum N=$ jumlah seluruh peserta didik 
Setelah dilaksanakan tes diagnostik, treatment diberikan kepada peserta didik. Treatment menggunakan pembelajaran dengan pendekatan konstruktivisme metode 5E. Pembelajaran diberikan satu kali pertemuan untuk setiap konsep pada materi gelombang bunyi.

\section{HASIL DAN PEMBAHASAN}

Perubahan konsep peserta didik diidentifikasi dengan menggunakan tes diagnostik dua tier (tingkat) sebagai alat pengumpulan data dan wawancara untuk mengkonfirmasi jawaban peserta didik. Pada tingkat pertama menyajikan pertanyaan pilihan ganda dengan alasan peserta didik memilih jawaban tersebut pada tingkat dua. Pada tier dua dilakukan analisis jawaban peserta didik paham konsep, miskonsepsi dan tidak paham konsep. Tes diagnostik dua tingkat menurut Caleon dan Subramaniam dalam Jubaedah dkk dapat mengukur kemampuan peserta didik dalam memilih jawaban yang benar serta alasan mengapa peserta didik memilih alasan tersebut. Dan menurut Mehrens dan Lehmann dalam Wahyuningsih dkk (2013) tes diagnostik dapat memberikan gambaran akurat mengenai miskonsepsi peserta didik berdasarkan kesalahan yang dibuatnya, serta lebih efisien apabila dilakukan wawancara untuk mengkonfirmasi atau menyinkronkan jawaban yang ditulis oleh peserta didik pada tes diagnostik (Suparno, 2010). Berikut hasil analisis tes diagnostik yang diperoleh (Tabel 3 dan 4).

Tabel 3 Distribusi Klasifikasi Jawaban Peserta Didik

\begin{tabular}{|c|c|c|c|c|c|c|c|}
\hline \multirow{2}{*}{ Konsep } & \multirow{2}{*}{ Indikator Soal } & \multicolumn{3}{|c|}{ Sebelum } & \multicolumn{3}{|c|}{ Setelah } \\
\hline & & PK & $\mathbf{M}$ & TPM & PK & $\mathbf{M}$ & TPM \\
\hline \multirow[t]{3}{*}{ Pipa organa } & $\begin{array}{l}\text { Menggambarkan } \\
\text { gelombang } \\
\text { berdiri pada pipa } \\
\text { organa tertutup }\end{array}$ & $42,86 \%$ & $39,29 \%$ & $17,86 \%$ & $91,67 \%$ & $0,00 \%$ & $8,33 \%$ \\
\hline & $\begin{array}{l}\text { Menggambarkan } \\
\text { gelombang } \\
\text { berdiri pada pipa } \\
\text { organa terbuka }\end{array}$ & $46,43 \%$ & $39,29 \%$ & $14,29 \%$ & $100 \%$ & $0,00 \%$ & $0,00 \%$ \\
\hline & $\begin{array}{l}\text { Mengaitkan } \\
\text { perubahan } \\
\text { volume udara } \\
\text { dengan nada } \\
\text { yang dihasilkan } \\
\text { pada tabung }\end{array}$ & $0,00 \%$ & $96,43 \%$ & $3,57 \%$ & $0,00 \%$ & $86,96 \%$ & $13,04 \%$ \\
\hline \multicolumn{2}{|c|}{ Jumlah Rata-Rata } & $29,76 \%$ & $58,34 \%$ & $11,91 \%$ & $63,89 \%$ & $28,99 \%$ & $7,12 \%$ \\
\hline
\end{tabular}


Tabel 4 Distribusi Klasifikasi Jawaban Peserta Didik

\begin{tabular}{|c|c|c|c|c|c|c|c|}
\hline \multirow{2}{*}{ Konsep } & \multirow{2}{*}{ Indikator Soal } & \multicolumn{3}{|c|}{ Sebelum } & \multicolumn{3}{|c|}{ Setelah } \\
\hline & & PK & $\mathbf{M}$ & TPM & PK & M & TPM \\
\hline \multirow{6}{*}{$\begin{array}{l}\text { Cepat rambat } \\
\text { gelombang } \\
\text { bunyi pada } \\
\text { medium udara }\end{array}$} & $\begin{array}{l}\text { Menganalisis amplitudo dan } \\
\text { frekuensi }\end{array}$ & $14,29 \%$ & $53,57 \%$ & $32,14 \%$ & $50,00 \%$ & $37,50 \%$ & $12,50 \%$ \\
\hline & $\begin{array}{l}\text { Menganalisis kecepatan } \\
\text { gelombang tidak bergantung } \\
\text { pada frekuensi }\end{array}$ & $3,57 \%$ & $60,71 \%$ & $35,71 \%$ & $73,91 \%$ & $21,74 \%$ & $4,35 \%$ \\
\hline & $\begin{array}{l}\text { Menganalisis kecepatan } \\
\text { gelombang bunyi di udara } \\
\text { tidak bergantung pada } \\
\text { frekuensi dan amplitudo }\end{array}$ & $0,00 \%$ & $32,14 \%$ & $67,86 \%$ & $91,30 \%$ & $0,00 \%$ & $8,70 \%$ \\
\hline & $\begin{array}{l}\text { Mengemukakan osilasi } \\
\text { partikel udara terganggu oleh } \\
\text { gelombang bunyi }\end{array}$ & $0,00 \%$ & $71,43 \%$ & $28,57 \%$ & $34,78 \%$ & $56,52 \%$ & $8,70 \%$ \\
\hline & $\begin{array}{l}\text { Mengkorelasikan frekuensi } \\
\text { gelombang bunyi dengan } \\
\text { osilasi }\end{array}$ & $3,57 \%$ & $46,43 \%$ & $50,00 \%$ & $39,13 \%$ & $43,48 \%$ & $17,39 \%$ \\
\hline & $\begin{array}{l}\text { Mengemukakan amplitudo } \\
\text { gelombang dengan osilasi }\end{array}$ & $3,57 \%$ & $60,71 \%$ & $35,71 \%$ & $26,09 \%$ & $21,74 \%$ & $52,17 \%$ \\
\hline \multicolumn{2}{|c|}{ Jumlah Rata-Rata } & $4,17 \%$ & $54,17 \%$ & $41,67 \%$ & $52,54 \%$ & $30,16 \%$ & $17,30 \%$ \\
\hline
\end{tabular}

Hasil analisis tes diagnostik menunjukkan pemahaman konsep dari 30 peserta didik yang menjadi objek penelitian (Tabel 3 dan Tabel 4). Persentase rata-rata jawaban peserta didik sebelum diberikan treatment dominan mengalami miskonsepsi. Jawaban peserta didik dengan persentase miskonsepsi paling tinggi $(96,43 \%)$ pada konsep pipa organa pada indikator soal mengaitkan perubahan volume udara dengan nada yang dihasilkan, diikuti indikator soal mengemukakan osilasi partikel terganggu oleh gelombang bunyi dengan persentase $71,43 \%$. Persentase jawaban peserta didik sangat tinggi pada klasifikasi miskonsepsi dapat disebabkan karena peserta didik memiliki intuisi yang salah, buku pelajaran dan metode pembelajaran yang kurang sesuai dengan materi (Silung, 2016)

Secara garis besar, meskipun persentase jawaban peserta didik miskonsepsi lebih tinggi dibandingkan tidak paham konsep pada setiap indikator soal. Terdapat satu indikator soal yang memiliki persentase tidak paham konsep lebih tinggi pada indikator soal nomer 3 , menganalisis cepat rambat gelombang tidak bergantung pada frekuensi dan amplitudo $(67,86 \%)$. Pada tes diagnostik awal tidak ada peserta didik yang dapat menyelesaikan soal dengan benar. Indikator soal ini paling sulit untuk diselesaikan oleh peserta didik (Barniol,2016). Hal ini karena peserta didik secara konsisten memberikan jawaban bahwa cepat rambat gelombang bergantung pada frekuensi sesuai dengan persamaan $v=\lambda f$ dan tidak dapat memberikan alasan mengapa memilih jawaban tersebut. Pada indikator soal nomer 7 dan nomer 8 yaitu konsep pipa organa, jawaban peserta didik lebih tinggi pada klasifikasi paham konsep. Jawaban tes diagnostik peserta didik paham konsep lebih tinggi dibandingkan persentase jawaban lain karena peserta didik telah menerima pembelajaran yang disajikan pada tes diagnostik. Peserta didik dapat memilih gambar dengan memberikan alasan yang benar (Gambar 1).

Dari jawaban tes diagnostik, dilakukan wawancara untuk mengkonfirmasi jawaban peserta didik. Berikut deskripsi wawancara antara peneliti dengan peserta didik pada indikator soal nomor 7 dan 8 . 
Peneliti

: Kamu yakin dengan jawaban yang kamu berikan ?

Peserta didik 1dan : Iya mbak saya yakin.

2

Peneliti

Peserta didik 1

Peserta didik 2

Peneliti

Peserta didik 1
: Mengapa kamu begitu yakin? Apa alasanmu memilih gambar ini (Gambar 1 dengan pilihan jawaban A)?

: Karena pada pipa organa terbuka udara akan langsung keluar.

: Karena pada soal yang diminta pada nada dasar jadi saya pilih gambar yang paling sederhana. Karena nada dasar dari pipa organa terbuka adalah $1 / 2$ panjang gelombang.

: Bagaimana dengan pipa organa tertutup?

: Ya, karena ujungnya tertutup udara tidak langsung dapat keluar dari ujung pipa.

: Sama saja mbak, dengan pipa organa terbuka, tetapi beda untuk nada dasarnya $1 / 4$ dari panjang gelombang.

Berdasarkan hasil jawaban tes diagnostik dan wawancara tersebut, peserta didik dapat menyelesaikan indikator soal ini karena menghafal gambar dan persamaan matematis dari pipa organa tanpa memahami konsep dari gambar dan persamaan tersebut.

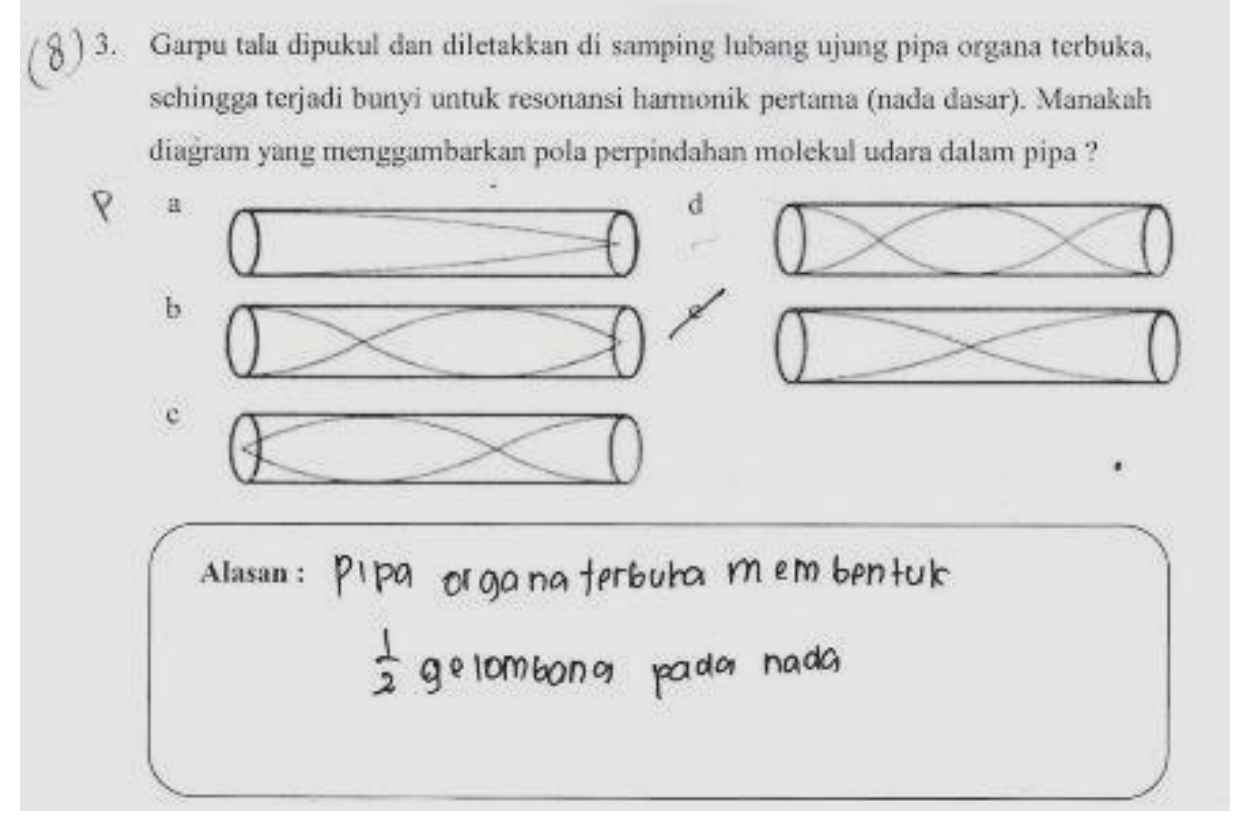

Gambar 1 Jawaban tes diagnostik peserta didik kategori paham konsep pada indikator soal nomor 8

Setelah peserta didik diberikan treatment, perubahan persentase jawaban peserta didik pada klasifikasi paham konsep mengalami peningkatan yang cukup signifikan (41\%). Peningkatan persentase jawaban paham konsep peserta didik dapat dikarenakan peserta didik telah mendefinisikan ulang konsep melalui interaksi dengan lingkungan belajar di kelas saat diberikan treatment. Sesuai dengan prinsip konstruktivisme, peserta didik secara aktif 
membentuk pengetahuan melalui kontak dengan lingkungan, tantangan, dan bahan yang dipelajari (Suparno, 2013).

Berdasarkan hasil penelitian, tingginya persentase miskonsepsi peserta didik sebelum treatment dikarenakan kurangnya pemahaman konsep cepat rambat gelombang bunyi dalam medium udara dan pipa organa. Pada konsep cepat rambat gelombang bunyi, peserta didik mengalami miskonsepsi dengan menganggap bahwa tinggi rendah gelombang bunyi sama dengan keras lemah dari gelombang bunyi, semakin tinggi frekuensi gelombang maka bunyi dapat menembus udara lebih cepat (Gambar 2), semakin tinggi perubahan frekuensi gelombang bunyi maka cepat rambat gelombang akan semakin tinggi dan partikel udara yang terganggu oleh gelombang bunyi akan menjauhi pengeras suara dan berosilasi sesuai gelombang transversal (Gambar 3). Sejalan dengan penelitian Sutopo (2016) bahwa bahwa hubungan $v=\lambda f$ belum dipahami oleh sebagian besar peserta didik. Mereka belum memiliki pemahaman yang benar bahwa frekuensi gelombang ditentukan oleh cara gelombang dibangkitkan (besarnya sama dengan frekuensi getaran sumber gelombang), cepat rambat gelombang bunyi hanya ditentukan oleh karakterikristik medium. Sedangkan pada konsep pipa organa, peserta didik menganggap bahwa jika panjang kolom udara lebih tinggi maka frekuensi akan semakin tinggi.

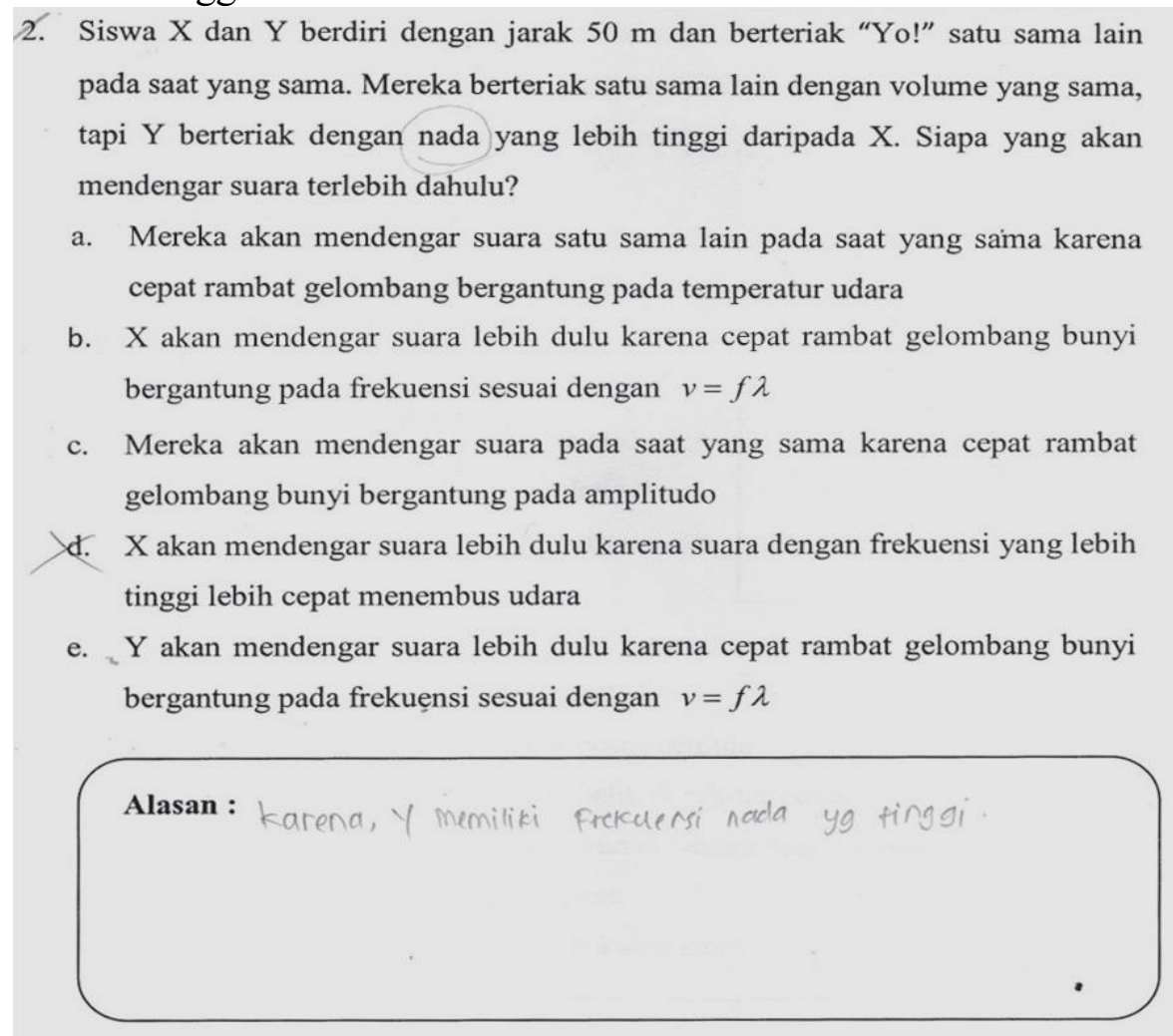

Gambar 2 Jawaban Salah Satu Peserta Didik Kategori Miskonsepsi Sebelum Treatment Pada Indikator Soal Nomor 2 


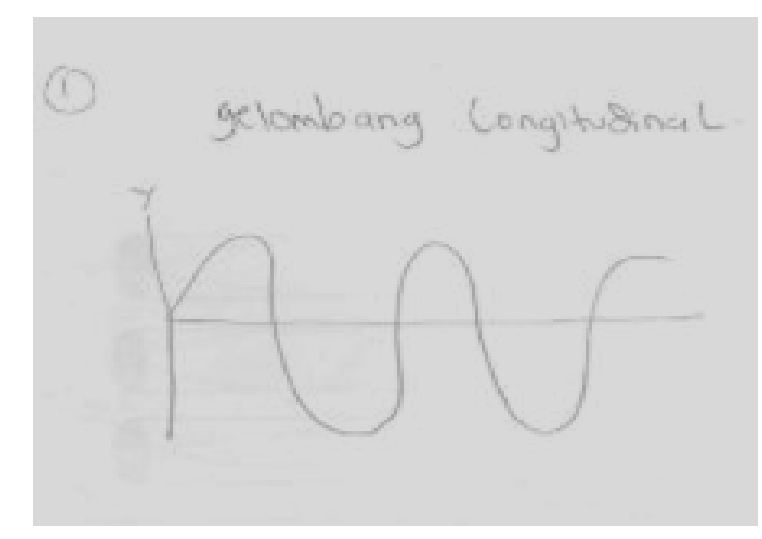

Gambar 3 Gambar Gelombang Longitudinal Oleh Peserta Didik

Konsepsi peserta didik pada konsep cepat rambat gelombang bunyi mengalami perubahan setelah diberikan pembelajaran menggunakan pendekatan konstruktivisme metode 5E. Setelah treatment, peserta didik dapat menyelesaikan soal dengan benar (Gambar 4). Peserta didik dapat memberikan alasan dengan tepat yaitu cepat rambat gelombang bunyi di udara bergantung pada temperatur udara. Dari jawaban tes diagnostik, dilakukan wawancara untuk mengkonfirmasi jawaban peserta didik. Berikut deskripsi wawancara antara peneliti dengan peserta didik pada indikator soal nomor 2 .

Peneliti : Kamu yakin dengan jawaban yang kamu berikan ?

Peserta didik : Iya mbak saya yakin.

Peneliti : Mengapa kamu begitu yakin? Apa alasanmu?

Peserta didik : Karena cepat rambat gelombang bunyi bergantung pada temperatur udara.

Peneliti : Apa maksud dari bergantung dengan temperatur?

Peserta didik : Ya, kalau suhu panas nanti bunyi akan merambat lebih cepat. Kalau suhu dingin akan merambat lebih lambat.

Dari hasil wawancara kepada peserta didik setelah diberikan treatment, peserta didik mampu menjelaskan bahwa bila frekuensi semakin tinggi atau rendah tidak berpengaruh pada cepat rambat gelombang bunyi tetapi pada nada bunyi yang dihasilkan dan temperatur udara akan berpengaruh pada cepat rambat gelombang bunyi. 
9. Siswa $\mathrm{X}$ dan $\mathrm{Y}$ berdiri dengan jarak $50 \mathrm{~m}$ dan berteriak "Yo!" satu sama lain pada saat yang sama. Mereka berteriak satu sama lain dengan volume yang sama, tapi $\mathrm{Y}$ berteriak dengan nada yang lebih tinggi daripada $\mathrm{X}$. Siapa yang akan mendengar suara terlebih dahulu?

d. Mereka akan mendengar suara satu sama lain pada saat yang sama karena cepat rambat gelombang bergantung pada temperatur udara

b. X akan mendengar suara lebih dulu karena cepat rambat gelombang bunyi bergantung pada frekuensi sesuai dengan $v=\lambda f$

c. Mereka akan mendengar suara pada saat yang sama karena cepat rambat gelombang bunyi bergantung pada amplitudo

d. $\mathrm{X}$ akan mendengar suara lebih dulu karena suara dengan frekuensi yang lebih tinggi akan lebih cepat menembus udara

e. Y akan mendengar suara lebih dulu karena cepat rambat gelombang bunyi bergantung pada frekuensi sesuai dengan $v=\lambda f$

Alasan :

karena, cepat rambat bungi bergamury pada

temperant

Gambar 4 Jawaban Salah Satu Peserta Didik Kategori Paham Konsep Setelah Treatment Pada Indikator Soal Nomor 2

Peningkatan pemahaman peserta didik setelah diberikan treatment pada indikator 2 ini dapat dilihat dari peningkatan persentase pemahaman konsep dan menurunnya persentase miskonsepsi jawaban peserta didik yang ditunjukkan oleh Tabel 4. Persentase jawaban paham konsep peserta didik mengalami peningkatan yang sangat signifikan, yakni sebesar $70,34 \%$ dan diikuti oleh menurunnya persentase jawaban miskonsepsi peserta didik sebesar $38,97 \%$. Perubahan persentase jawaban peserta didik setelah diberikan treatment menunjukkan bahwa peserta didik memiliki pemahaman yang lebih baik untuk dapat menyimpulkan cepat rambat gelombang bunyi tidak bergantung pada frekuensi.

Berdasarkan pemaparan konsepsi peserta didik, treatment yang diberikan dapat menurunkan jumlah rata-rata miskonsepsi peserta didik sebesar $26 \%$ dan meningkatkan ratarata pemahaman konsep peserta didik (41\%). Penurunan jawaban miskonsepsi peserta didik menunjukkan bahwa pembelajaran dengan pendekatan konstruktivisme metode $5 \mathrm{E}$ dapat menurunkan miskonsepsi peserta didik pada materi gelombang bunyi. Hasil ini sesuai dengan penelitian Taufiq (2012) bahwa pembelajaran 5E dapat menurunkan persentase miskonsepsi dan menurunkan jumlah peserta didik yang mengalami miskonsepsi serta dapat meningkatkan pemahaman peserta didik.

Perubahan konsepsi peserta didik dimulai pada langkah kedua metode 5E yaitu langkah explore. Langkah explore bertujuan untuk memberikan pengalaman peserta didik melalui percobaan yang memungkinkan peserta didik untuk membangun konsep (restrukturisasi ide). Peserta didik dapat membangun konsep mereka melalui pengumpulan informasi, pengamatan 
dan berdiskusi. Proses diskusi diperlukan untuk menyatukan pendapat peserta didik ketika melakukan percobaan.

Selanjutnya, pendidik memberikan kesempatan kepada peserta didik untuk mengungkapkan ide/gagasan yang didapatkan pada langkah explore. Setelah peserta didik mengungkapkan gagasannya, pendidik memberikan klarifikasi jika ditemukan miskonsepsi pada peserta didik (langkah explain) seperti pada Gambar 5. Klarifikasi diberikan untuk membenarkan konsep peserta didik dalam memahami konsep yang diberikan. Pada langkah explain, pendidik memberikan klarifikasi dengan menampilkan video pembelajaran yang menjelaskan bagaimana gerakan partikel udara yang terganggu oleh gelombang bunyi dan gambar posisi amplitudo pada gelombang longitudinal.

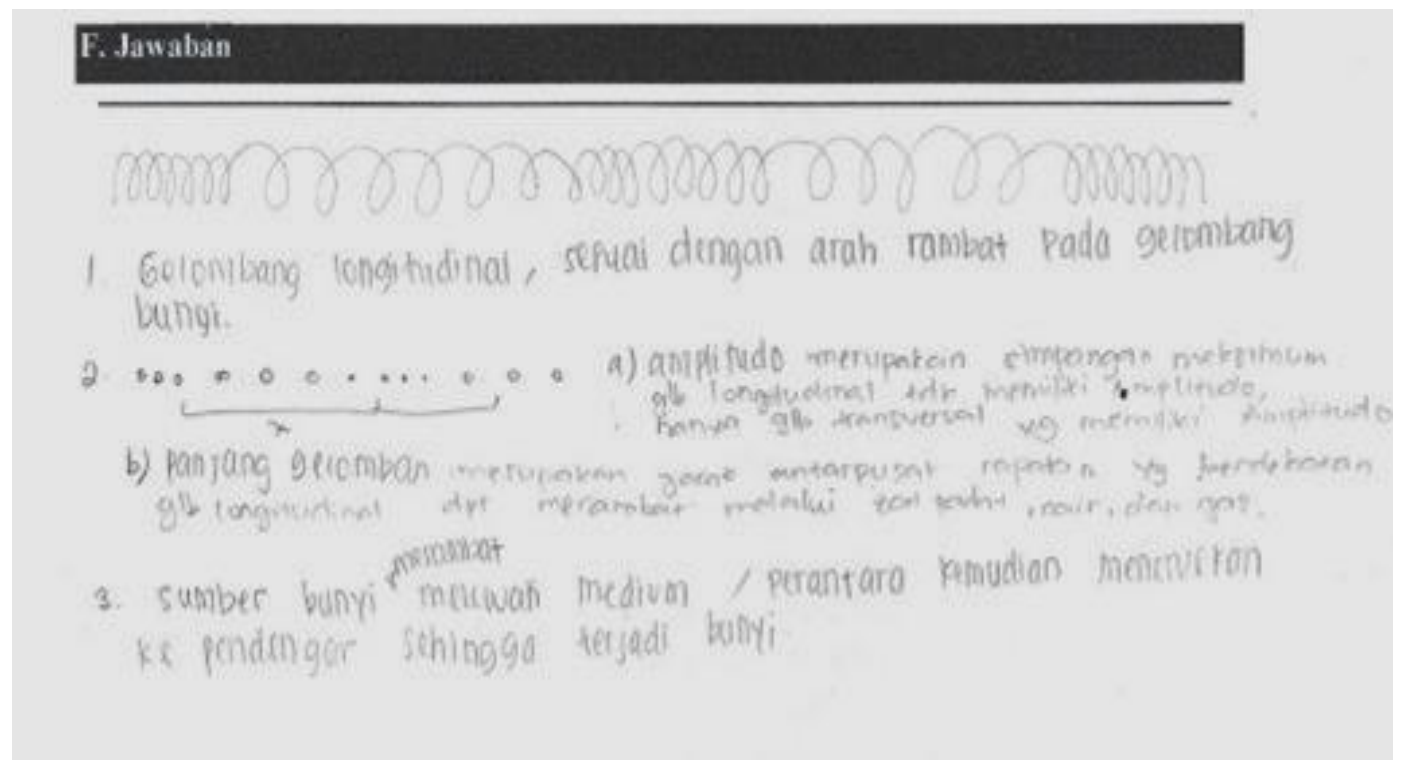

Gambar 5 Jawaban Peserta Didik Pada LKPD Pertama

Pada gambar 5 terlihat bahwa peserta didik telah dapat memahami bahwa gelombang bunyi menurut arah getarnya merupakan gelombang longitudinal. Namun, peserta didik tidak dapat menentukan dengan benar posisi amplitudo gelombang.

Setelah peserta didik mendapatkan konsep yang benar dari klarifikasi yang diberikan oleh pendidik, peserta didik diberikan tantangan untuk mengaplikasikan konsep yang telah dipelajari melalui langkah extend. Pada langkah ini, pendidik memberikan studi kasus dengan inti masalah yang sama dengan tes diagnostik yang diberikan, yaitu cepat rambat gelombang bunyi tidak dipengaruhi oleh frekuensi bunyi dan membandingkan panjang gelombang pada pipa organa terbuka serta pipa organa tertutup. Langkah ini merupakan langkah yang penting untuk mengetahui bagaimana miskonsepsi yang dialami peserta didik pada konsep yang telah dipelajari.

Langkah terakhir dari pembelajaran metode 5E adalah evaluate. Pada langkah ini, pendidik mengevaluasi pemahaman peserta didik dalam mengaplikasikan konsep (Taufiq, 2012). Evaluasi dilakukan agar peserta didik tidak kembali mengalami miskonsepsi dalam mengaplikasikan konsepnya.

\section{PENUTUP}

Hasil penelitian ini menunjukkan bahwa peserta didik mengalami miskonsepsi pada materi gelombang bunyi dengan konsep cepat gelombang bunyi di udara dan konsep pipa organa. 
Penggunaan tes diagnostik two tier dalam penelitian ini sangat membantu peneliti untuk mengidentifikasi pemahaman konsep peserta didik. Setelah diberikan pembelajaran menggunakan pendekatan konstruktivisme metode 5E efektif untuk meminimalkan rata-rata miskonsepsi peserta didik sebesar 26\%.

Peneliti memberikan saran untuk mengidentifikasi dan meremediasi miskonsepsi materi gelombang bunyi hanya dilakukan pada jenjang Sekolah Menengah Atas (SMA), padahal peserta didik di SMP telah mendapatkan materi gelombang bunyi. Untuk peneliti selanjutnya, dapat mengidentifikasi persamaan atau perbedaan miskonsepsi pada jenjang pendidikan SMP dan SMA.

\section{DAFTAR PUSTAKA}

Altun, Sertel dkk. (2015). The Methods of Teaching Course Based on Constructivist Learning Approach: An Action Research. Journal of Education and Training Studies.

Amina, Sari. A.R. dkk, (2017). Profil Pemahaman Konsep Dasar Gelombang Mekanik Siswa SMA. Seminar Nasional Pendidikan Sains II UKSW

Barniol, Pablo et al. (2016). The Mechanical Waves Conceptual Survey: Its Modification and Conversion to A Standart Multiple-Choice Test. Physical Review Physics Education Research. 12 (010107).

Berg, Euwe V.D. (1991). Miskonsepsi Fisika dan Remediasi. Salatiga: Penerbit Universitas Kristen Satya Wacana

Ergin, Ismet. (2012). Constructivist Approach Based 5E Model and Usability Instructional Physics. Edvcatio Physicorvm. 6(1).

Jubaedah, D. Siti dkk. (2017). Pengembangan Tes Diagnostik Berformat Four - Tier Untuk Mengidentifikasi Miskonsepsi Siswa Pada Topik Usaha Dan Energi. Prosiding Seminar Nasional Fisika.

Silung, dkk. (2016). Diagnosis Miskonsepsi Siswa SMA di Kota Malang dan Konsep Suhu dan Kalor Menggunakan Three Tier Test. Jurnal Pendidikan Fisika dan Teknologi.

Siswaningsih, W dkk. (2017). Development of Two-Tier Diagnostic Test Pictorial-Based for Identifying High School Students Misconceptions on the Mole Concept. Journal of Physics:Conference Series.

Suparno, Paul. (2010). Metodologi Pembelajaran Fisika: Konstruktivistik \& menyenangkan. Yogyakarta : Universitas Sanata Dharma.

Suparno, Paul. (2013). Metodologi Pembelajaran Fisika: Konstruktivistik \& menyenangkan. Yogyakarta : Universitas Sanata Dharma.

Sutrisno, Leo dkk. (2007). Pengembangan Pembelajaran IPA SD. Surakarta:PGSD FKIP UMS.

Sutopo (2016). Pemahaman Mahasiswa Tentang Konsep-Konsep Dasar Gelombang Mekanik. Jurnal Pendidikan Fisika Indonesia. 12(1), 41-53

Taufiq, Muhammad. (2012). Remediasi Miskonsepsi Mahasiswa Calon Guru Fisika Pada Konsep Gaya Melalui Penerapan Model Siklus Belajar (Learning Cyrcle)5E. Jurnal Pendidikan IPA Indonesia Vol. 1 No. 2.hlm. 198-203. Oktober 2012.

Tongchai, Apisit et al. (2009). Students' Conceptual Knowledge of Mechanical Waves Across Different Backgrounds and Cultures. Symposium Presentation.

Viridi, Sparisoma. (2008). Miskonsepsi dalam Fisika. Berita Pembelajaran, No.2, Tahun1. Bandung:ITB.

Wahyuningsih, Tri dkk. (2013). Pembuatan instrumen tes diagnostik fisika kelas SMA kelas XI. Jurnal Pendidikan Fisika Vol. 1 No. 1. April 2013. 